\title{
Perekond poola naljades
}

\author{
Dorota Brzozowska
}

Teesid: Artiklis kirjeldatakse pereelu kuvandit Poola postsotsialistlikes naljades. Tänapäevane materjal (alates 1990. aastate lõpust kuni praeguse ajani) on kogutud vastavasisulistest raamatutest, brošüüridest, ajalehtedest ja internetist, analüüsitud on 600 nalja (vrd ka üldisem ülevaade poola naljade muutumisest Brzozowska 2009). Kuna pereelust ei ole eraldi naljade tsüklit, on arvesse võetud erinevaid naljatekste, kus esinevad sõnad "naine", "mees", "laps" või nende sünonüümid. Uuringu tulemused näitavad, et naljades esineb mitmeid püsitegelasi, näiteks agressiivsed ämmad või truudusetud naised. Uusi teemasid ei ole eriti lisandunud: puuduvad naljad isapuhkuse kohta, mis alles hiljuti võimalikuks tehti ja mille üle ka meedias palju arutleti, samuti ei leidu nalju joobes naistest, kuigi probleem on ühiskonnas olemas ja naistel on üha rohkem lubatud avalikes kohtades alkoholi tarbida. Kokkuvõtvalt võib antud uuringu põhjal väita, et pereteemalised naljad ei käsitle jooksvaid ega päevakajalisi sündmusi, vaid on pigem jäänud peamiselt traditsiooniliseks, kajastades teatud kindlaid korduvaid teemasid, mis kuuluvad rahva kultuuripärandi keskmesse.

Märksõnad: Poola perenaljad, postsotsialistlikud naljad, stereotüübid naistest, tuumpere

\section{Sissejuhatus}

Artiklis tuuakse välja sooliste aspektide olemasolu poola naljades, ${ }^{1} \mathrm{kus}$ tegelasteks on naised, mehed ja lapsed. Naljaobjekte kujutatakse kõige sagedamini just privaatsfääris.

Naljades esitatakse poola perekonda enamasti tuumperena, kus on ema, isa ja laps, tavaliselt poeg Jasio või Kazio. Poola naised esinevad naljades abielunaistena, kes kalduvad sageli rikkuma abielu. Mehed on joodikud, ei hoolitse oma laste eest ega ole huvitatud kodutööde tegemisest. Lapsed on targemad kui nende vanemad või õpetajad. Mõnikord sekkuvad pereellu ämmad või vanaisad. Uuemates naljades on stabiilne ja traditsiooniline meeste-naiste maailma vastandus muutunud, sest sooküsimusi käsitletakse feministlikust vaatenurgast. 
Käesoleva artikli jaoks on kokku kogutud materjal alates 1990. aastate teisest poolest kuni praeguse ajani (vrd Brzozowska 2003). Allikateks on raamatud, brošüürid, ajalehed ja internet. Kuna pereelu kohta ei ole eraldi naljade tsüklit, on arvesse võetud erinevaid naljatekste, kus esinevad sõnad "naine", "mees", "laps" või nende sünonüümid. Kokku analüüsiti 600 nalja - kõigist kolmest kategooriast kakssada teksti. Uuringu peamine eesmärk oli kontrollida, milline pilt antakse pereelust postsotsialistlikes naljades, kuna need naljad on tekkinud aastail, mil majanduspoliitiline olukord stabiliseerus ja elukvaliteet muutus üsnagi rahuldavaks.

Mind huvitab küsimus, kuidas kujutatakse naljades avalikku ja privaatsfääri, kuidas need seostuvad stereotüüpsete meeste ja naiste rollidega ühiskonnas (vt Jędrzejko 1994) ja mil määral tuleb esile patriarhaalne maailmapilt, nagu see oli tavaks varasemates, enne 1990. aastaid ringelnud naljades.

\section{Abielu}

Kõige arvukam rühm nalju käesolevas valimis (ca 30\%) on naistest kui abikaasadest - see on roll, millega kaasneb palju sissejuurdunud stereotüüpe naistest, vastandatuna meestele. "Naise ja mehe stereotüübi olemasolu on markantne ning sel on tähenduslik roll inimeste sotsiaalsete uskumuste seas [...]. Stereotüüpselt nähakse naisi soojade ja ekspressiivsetena, samas kui mehed on ratsionaalsed ja efektiivsed oma tegudes" (Nęcki 2000). Abielurikkumise skript on neis naljades kõige populaarsem.

"Styszałem, że twoja żona zaliczyła całe miasto?"

"Téz mi miasto, pięć tysięcy mieszkańców."

["Ma kuulsin, et su naine on kogu linnaga maganud?" - "Viis tuhat inimest - kas sa nimetad seda linnaks?"]

(Ale jaja. O kobietach 12/97)

Truudusetuna kujutatakse naljades mitte üksnes Poola naisi, vaid ka nende meestel on abieluväliseid suhteid:

“Tato - zali się córka Kowalskiemu - mąż mnie zdradza. Co mam robić?” "Poczekaj na mamę, ona ma większe doświadczenie w tej sprawie."

["Issi," kaebleb Kowalski tütar, "mu mees petab mind, mida ma peaksin tegema?" - "Küsi oma emalt, tal on selles asjas rohkem kogemusi."]

(Świeże dowcipy. O kelnerach 7/97) 
Paljudes uuritud naljades on tegelaseks armuke, ka on märkimisväärselt palju nalju lahutusest. Need kaks teemat on tihedalt seotud, sest päriselus peab enamik paare peamiseks lahutuse põhjuseks just truudusetust.

Tänapäeval on naistel rohkem võimalusi neid mitte rahuldava abielu lõpetamiseks kui mõned aastakümned tagasi. Statistika kohaselt on just naised need, kes tunnevad end abielus sagedamini õnnetuna, ja algatavad koguni 70\% kõigist lahutustest (Poola Õigusabi portaal 2012). Lahutuste arv on kiiresti kasvanud, ja kuigi peamiselt abiellutakse kiriklikult ning Poola peamine religioosne institutsioon roomakatoliku kirik ei luba abielu lahutada, on purunevate abielude arv siiski suurenemas.

"Czy jest pan rozwiedziony?”

"Jeszcze nie."

["Kas te olete lahutatud, härra?" - "Veel mitte."]

(Coś z dowcipami. O facetach 11/97)

Mõnikord kestab abielu palju kauem, kui abikaasad sooviksid. Veel üks skript poola naljades räägib naistest, kes on juba surnud, kuid oma ikka veel elavatele meestele veskikiviks kaelas:

“Nie ptacz, czyżbyś nie wierzyt, że spotkasz się ze swoja żona w niebie?!” pociesza przyjaciel wdowca.

"Wierzę $i$ dlatego ptaczę!"

[“Ära nuta, kas sa siis ei tea, et kohtud oma naisega taevas?!” lohutab sõber leske. - "Ma usun, et ma pean temaga tõesti veel kohtuma, sellepärast nutangi!"]

(Dowcip za dychę 6-7/94)

Teisalt näitab statistika, et lesestunud mees ei suuda enda eest korralikult hoolitseda ja sureb sageli üsna varsti pärast abikaasat või soovib ta leida endale uue naise niipea kui võimalik - kiiremini kui naised samas olukorras (Szukalski 2011). Sellised tõigad avalduvad tihti ka naljades:

Po pogrzebie do wdowca podchodzi jego najlepszy przyjaciel i mówi: "Nie załamuj się, stary. Za rok, dwa znajdziesz sobie jakąś mita babkę, która cię pocieszy."

"Za rok? A co ja będę robit dziś wieczorem?"

[Pärast matust ütleb parim sõber leskmehele: "Ära ole nii murtud. Aastapaari pärast leiad ühe kena seeliku ja saad temast lohutust." - "Aasta pärast? Aga mida ma täna öösel teen?"]

(Coś z dowcipami. O facetach 11/97) 


\section{Alkohol}

Alkoholi tarvitamine on üks peamisi probleeme abielusuhetes. Ka siinses uuringus on see teema väga sage. Purjusolek on naljades meeste pärusmaaks, põhjustades arvukaid kodutülisid, mille käigus püüab naine veenda oma abikaasat joomist lõpetama - kahjuks enamasti tulemusteta.

Kolega zwierza się Kowalskiemu: "Moja stara przysięgła, że mnie zostawi, jak nie przestane pić."

"No i co?"

"No, będzie mi jej brakowato."

[Sõber puistab Kowalskile südant: "Mu naine lubas, et ta läheb mu juurest ära, kui ma joomist ei lõpeta." - "Ja sina?" - "Ma hakkan teda taga igatsema."]

(www.dowcipy.celebs.pl/pijacy.html)

"Joomiskultuur" on viimastel aastatel läänemaailma mõjul kiiresti muutunud (Labus 2011) - õlu on üha populaarsem, tekkinud on spetsiaalsed õllebaarid, intensiivselt reklaamitakse paljusid pruulikodasid ja tuhandeid uusi pubisid. Kommunistliku režiimi ajal jõid mehed peamiselt kodus, sageli just keelatud omatehtud alkoholi - puskarit. Õllejoomist seostati toona peamiselt pättidega, ühiskonna marginaalse kihistusega õlleputkade ümbruses.

Iga aastaga on lahjade alkohoolsete jookide läbimüük Poolas suurenenud, ja samas on tõusnud ka sotsiaalne teadlikkus alkoholi tarbimise kahjulikest mõjudest. ${ }^{2}$ Huvitav on asjaolu, et alkoholivastased sotsiaalkampaaniad, mis on viimasel ajal väga populaarseks muutunud, on tugeva soolise kaldega. Populaarne üleskutse "Kui oled joonud, ära autot juhi" on suunatud ainult meestele, see avaldub ka sotsiaalreklaami sõnavalikus.

"Tyle się złego naczytałem na temat alkoholu - mówi Antek do kolegi-że wreszcie sobie powiedziatem, czas raz na zawsze z tym skończyć!”

"Z piciem?"

"Nie, z czytaniem."

["Ma olen alkoholi kohta nii palju halba lugenud," räägib Antek oma sõpradele, "et ma lubasin endale, et jätan selle ühekorraga ja igaveseks järele!” - “Jätad joomise järele?” - "Ei, lugemise.”]

(Xsięga humoru 1999: 191)

Alkoholiteemalisi nalju räägitakse meeleldi just neis kogukondades, kus prevaleerib poissmehekultuur. Poola kultuur on vallaliste meeste kultuur, kus domineerib maskuliinne solidaarsus ja võrdsus, kus meestevaheline sõprus on olulisem kui perekond (vrd. Davies 1990: 56 tähelepanekud Austraalia kohta). 
Sõbrad on perekonna aseaineks ja rivaaliks; koos räägitakse spordist, autodest ja naistest, koos käiakse jahil või kalal. Joomine tõestab meeste võrdsust, solidaarsust ja maskuliinsust ning hõlbustab suhete loomist. Mehed, järgides macho-kuvandit "poisid ei nuta", on tugevad, kontrollivad oma tundeid ega taha teisi usaldada. Alkoholi mõju, mis võimaldab neil neist reegleist üle astuda, annab meestele julguse stereotüüpe lõhkuda.

Joodikunaljade aluseks on töö ja tootmisega seotud väärtuste ning tarbimise, jõudeelu ja pidutsemise hedonistlike väärtuste vastandamine. Sellised tekstid toimivad isoleeritud meestegruppides või rühmades, kus mehed ja naised täidavad selgelt määratletud ja erinevaid rolle (Davies 2002). Need rollid on üheselt olemas ka naljades, kus tegelasteks on naine ja tema joodikust mees.

Przychodzi mąż do domu wieczorem, oczywiście na lekkim cyku. Żona pyta: "Gdzie byteś?"

"Na szachach."

"To czego śmierdzisz piwem?”

"A czym mam śmierdzieć, szachami?"

[Mees tuleb õhtul koju ja on napsine. Naine küsib: "Kus sa olid?” - "Mängisin malet." - "Miks ma siis sinu juures õlle lõhna tunnen?" - "Mille järgi ma siis sinu arust peaksin lõhnama, male järgi või?"]

(www.forum-akm.net/viewtopic.php?Topic)

Naljad joodikutest on eriti populaarsed kogukondades, kus suhtumine alkoholi on kahetine - seda peetakse naudingute allikaks, kuid teisalt ka tõsiseks probleemiks. Tavaliselt naljatatakse mõlema äärmuse üle, naeruvääristatakse nii liigjoomist kui täiskarsklust (Davies 2011: 132-134). Ka poola naljade puhul on see täheldatav, kui teemaks on joomine ja (joodiku abikaasast) naise roll, kuid samas ei ole täiskarsklaste kohta käivad naljad eriti populaarsed.

\section{Lapsevanemad}

Olulise osa poola huumorist moodustavad naljad emadest (vt ka Brzozowska 2008). Emafiguur on poola kultuuris äärmiselt tähtis; öeldakse koguni, et ema kuulub pühasse sfääri; samas kui soovitakse prostituuti tähistavat vandesõna veelgi tugevamalt rõhutada, kasutatakse 'ema' tähistava sõna vanemat vormi - mać. Üks nalja atribuutidest ongi pühaduse rüvetamine, seega on mõistetav, miks naljade rääkijad ei kõhkle emasid nalja objektina kasutamast.

Kuigi enamik ema-nalju ei kuulu ühe kindla struktuuriga tüübi alla, kasutatakse mõnes naljas siiski samasugust algusmudelit - on nalju, mis algavad sõnaga mamo (ema) või mamusiu (emme), ja seda korratakse, et rõhutada 
väljendusrikkust. Poola naljades on peamiselt ema see, kes aitab oma lapsel (tavaliselt pojal, kuna poiss-tegelasi on siin analüüsitud naljades kuus korda rohkem kui tüdrukuid) teha kodutöid ning küsib, kuidas koolis läks.

"Mamo, dziś na lekcji pan od matematyki pochwalił mnie!” mówi Jasio.

"To bardzo tadnie, a co powiedziat?"

“Że wszyscy jesteśmy idiotami, a ja - największym!"

[“Ema, matemaatika õpetaja kiitis mind täna!” ütleb väike Jasio. - “Oo, see on väga tore. Mis ta ütles?” - "Et me oleme üks idiootide kamp ja mina olen selles osas teistele lausa eeskujuks.”]

(Xięga Humoru 1999: 51)

Kui aga isa aitab lapsel koolitöid teha, siis on ta nalja sihtmärgiks oma ebakompetentsuse tõttu.

Jasio odrabia zadanie domowe z geografii. W pewnej chwili pyta ojca: “Tato, gdzie leża Batkany?”

"Mamy zapytaj. Ona robiła porządki w szafie."

[Jasio teeb geograafia kodutööd ja küsib isalt: "Issi, kus on Balkanid?" "Küsi emalt, tema koristas riidekappi."]

(www.kawaly-o-jasiu.dimz.pl/rodzice2.html)

“Jasiu, masz dziś bardzo dobrze odrobione zadanie,” mówi nauczycielka. "Czy jesteś pewien, ze twojemu tacie nikt nie pomagat?"

[“Jasiu, sul on kodutöö väga hästi tehtud," ütleb õpetaja. "Kas sa oled kindel, et keegi su isa ei aidanud?"]

(http://wienmar.republika.pl/dowcipy.htm)

Laste arv peres on vähenenud: keskmises Poola peres on ainult üks või kaks last. ${ }^{3}$ Rohkem kui iga viies abielu on lastetu ning iga neljas laps on sündinud väljaspool abielu; esineb ka teismeliste rasedusi (Żmudzka-Kosała 2010).

Matka do córki: "O której ty wracasz do domu!!! Ja w Twoim wieku...”

"Wiem, wiem - przerywa dziewczyna - w ogóle nie wychodziłaś z domu bo ja miałam pięć miesięcy.”

[Ema ütleb tütrele: "Mis kell sa koju tuled!!! Kui mina olin sinu vanune..." - "Ma tean," katkestab tütar, "sa ei käinud üldse kodust väljas, sest mina olin alles viiekuune."]

(http://www.webhumor.pl/kawaly-dowcipy/kobieta)

Kuigi viljatus on muutunud suuremaks probleemiks (vt www.familie.pl) kui varasematel aegadel, on see siiski naljades üsna harva teemaks. 
Kobieta przychodzi do kliniki na zaptodnienie in vitro: "Panie doktorze. Syn ma być silny jak Arnold Schwarzenegger, przystojny jak Leonardo DiCaprio i madry jak Einstein."

Doktor kiwa głowa, daje jej środek nasenny, ściaga spodnie i zabiera się do dzieła, mruczac pod nosem: "Ja ci dam Schwarzeneggera..."

[Naine läheb kunstliku viljastamise kliinikusse: "Doktor, ma tahan, et mu poeg oleks sama tugev kui Arnold Schwarzenegger, sama ilus kui Leonardo DiCaprio ja sama tark kui Einstein." - Meesarst noogutab, annab naisele unerohtu, võtab endal püksid jalast ja asub tööle, ise pomisedes: "Siin on sulle su Schwarzenegger!"]

(http://dowcipy-o-kobietach.humoris.pl/dowcip/13432)

\section{Täiskasvanud laste vanemad}

Vanemate ja laste vahelised suhted on väga tugevad, olenemata poja või tütre vanusest:

Chtopak pyta swoja dziewczynę: "Opowiadasz o nas swojej mamie?" "Coś ty! Mama o nic nie pyta. Za to mój mąż jest okropnie ciekawski." [Poiss küsib oma tüdrukult: "Kas sa räägid oma emale meist?" - "Ole nüüd! Mu ema ei päri midagi, aga mu abikaasa on küll väga uudishimulik."]

(Ale Jaja. O kobietach 12/97)

Przychodzi mama Jasia do biura pośrednictwa pracy, żeby synowi robote jaka załatwić: "Pani, nie bytoby dla Jasia jakieś roboty, bo pije chtopak i pije ..."

"A co Jasiu potrafi?"

"No murować umie, podstawówkę skończyt..."

"A to mamy: murarz, 4000 na rękę..."

"Pani kochana! Toć przecież Jasiu cały czas będzie chodzit pijany, jak tyle pieniędzy zarobi... A za mniej coś nie ma?”

"No jest jeszcze - pomocnik murarza, 3000 na rękę..."

"No ale 3000? To przecież będzie pit i pit ... A tak za 600-700 złotych to coś by się nie znalazło?”

"600-700 ... Hmmm... To by Jasio musiat studia skończyć..."

[Jasio ema läheb tööhõiveametisse, et oma pojale tööd leida: "Proua, kas teil on mu Jasiole tööd pakkuda, poiss joob liiga palju..." - "Ja mida Jasio oskab teha?" - "Ta oskab telliskive laduda, ta on lõpetanud algkooli..." 
- "Jah, meil on tõesti müüriladujale tööd, 4000 poola zlotti netopalk..." - "Aga proua! Kui Jasio nii palju teenib, siis on ta kogu aeg purjus! Kas teil ei ole midagi väiksema tasu eest pakkuda?" - "On ka müüriladuja abilise ametikoht, 3000 zlotti neto..." - "Oi, 3000? Siis ta hakkab kõvasti jooma ... Aga kas on midagi 600-700 zloti eest?” - “600-700?... Hmmm... Selleks peaks Jasio olema ülikooli lõpetanud...”]

(www.dowcipy.jeja.pl/nowe,8,jasiu,26.html)

On ka uus, väga populaarne naljade tsükkel, mis peamiselt levib internetis, ja märgistab solvavalt emasid. Need naljad on tuntud koondnimetuse "sinu vana" (Twoja stara) all. Tavaliselt on tegu üherealiste naljadega, mis rõhutavad kõnealuste naiste rumalust või inetust.

Twoja stara myje ptyn do naczyń :D

Twoja stara ma takie worki pod oczami, że nosi w nich kartofle.

[Sinu vana peseb nõudepesuvedelikku :D

Sinu vanal on silmade all nii suured kotid, et ta kannab neis kartuleid.] (http://www.kiermana.pl/88-1-twoja,stara.html\#axzz1xZ6VF7sy)

Vildaka identiteedi või sooküsimuste temaatika on Poola naljades üha sagedasem, ja kuigi see pole peateema, moodustab see siiski omaette uue tsükli:

Raz, dwa, trzy, twoja stara to TY.

[Üks, kaks, kolm, sinu vana on - SINA.]

(http://www.kiermana.pl/88-1-twoja,stara.html\#axzz1xZ6VF7sy)

Twoja stara to ten prawej.

[Sinu vana on mees paremal.]

(http://www.kiermana.pl/88-1-twoja,stara.html\#axzz1xZ6VF7sy)

\section{Isad}

Poola naljad kinnitavad keelelise maailmapildi alaste uurimuste tulemusi, ${ }^{4} \mathrm{mis}$ näitavad, et kõige olulisem aspekt ema stereotüübi puhul on tema hariduslik funktsioon, mis on väga väärtuslik, eriti olukorras, kus isa tähtsus üha väheneb. Sotsioloogid väidavad, et keskmine Poola pere ei ole enam patriarhaalne ning väga sageli kasvatavad lapsi ainult emad. Isa roll laste üleskasvatamises on minimaalne või olematu. Poolas viimasel ajal avaldatud publikatsioonid tõestavad selle probleemi olulisust ja üha kasvavat teadlikkust põlvkonnast, kelle "isad on nad reetnud" (Eichelberger 1998). 
"Żona zarzuca mi, że nie troszczę się o dzieci. To jest nie do zniesienia!" "A ile ma pan dzieci?"

"Dwoje ... A może troje?"

["Mu naine väidab, et ma ei hoolitse laste eest. Ma ei suuda seda enam taluda!" - "Mitu last sul on?" - "Kaks ... või võibolla kolm?"]

(Coś z dowcipami. O facetach 11/97)

Stereotüüpide uuring kriipsutab eriti alla asjaolu, et ema- ja isakuvandiga kaasnevad ka mitmed kõrvaltähendused (Panasiuk 1998). Uuringutulemused näitavad, et me seostame heasoovlikkust ja armastust emaga, kusjuures isaga seondub raha, karmus ja töö. Kuid ka poola isad on hoolivad, neile meeldib lastega mängida ning nad soovivad veeta võimalikult palju aega koos oma lastega. See aga ei meeldi nende ülemustele, kes ei luba isadel töölt lahkuda enne kella nelja pärastlõunal, ka ei võta tööandjad nende isapuhkuse avaldusi piisavalt tõsiselt. Sageli teevad poola isad üleajatööd ja selle tulemusena veedavad nad lastega ainult keskmiselt 53 minutit päevas (Pawłowska).

\section{Lapsed}

Üks naljasari, mis kujutab ema ja poja suhteid, on puudega Jasiost - ema toetab nendes naljades oma last, valetades tolle seisundi kohta, et poeg end paremini tunneks, kuid samas reedab end, paludes pojal teha kummalisi asju:

Przychodzi Jasio do domu i mówi: "Mamo, wszyscy się ze mnie śmieją $i$ mówia, że mam duże uszy!"

"Nie masz, synku, ale idź na dach i nadstuchuj, czy tato jeszcze nie wraca $z$ Paryża."

[Jasio tuleb koju ja ütleb emale: "Ema, kõik naeravad mu üle ja ütlevad, et mul on suured kõrvad!" - "Ei ole sul suured kõrvad midagi, pojake, aga mine katusele ja kuulata, kas su isa juba hakkas Pariisist tagasi tulema."] (Dobry Humor. O kurach 8/1996)

Laste nimed ei ole poola naljades kuigi mitmekesised, kõige sagedasem poisinimi on Jaś, Jasio. On ka teisi poisslaste nimesid - Kazio, Jacek, Tomek. Aeg-ajalt on kasutusel ka tüdrukunimi, ja tavaliselt on see Kasia. Kuid kõige sagedamini on nalja peategelane lihtsalt nimeta poeg, väike poeg või poiss. 


\section{Ämmad}

Naljad kinnitavad tavaarusaama, et ema-stereotüüp vastandatakse kasuema ja ämma omale. Kahe viimase stereotüüpne kuvand on äärmiselt negatiivne. Domineerivateks joonteks on võõristus ja vaenulikkus (Bartmiński 1998). Ämma mõiste puhul on kaastähendusteks nõid, õelus ja nuhkimine. Äia kuvand on palju positiivsem ja seostatav selliste sõnadega nagu hea, tuhvlialune, isafiguur ja meelerahu (Panasiuk 1998). Nalju äiade kohta ei ole, kuid ämmadest on neid palju, ja ämmaks on ikka naiseema. Seda naljade kategooriat iseloomustab meeste ülekaal naljategelaste valikul.

Ämmanaljade ühisnimetaja seostub semantiliselt iseloomuliku agressiivsusega. Tavaliselt on need naljad meeste solidaarsuse ilminguks. Isegi kui mõni mees juhtub oma ämma tunnustama, veenavad ta sõbrad teda üsna ruttu selles, et ta on täiesti valel teel:

Na posterunku policji dzwoni telefon: "Ratunku, moja teściowa chce wyskoczyć przez okno!” krzyczy głos w stuchawce.

“A co, okno się zacięto i nie może go pan otworzyć?” domyśla się życzliwie policjant.

[Politseijaoskonnas heliseb telefon: "Aidake, mu ämm tahab aknast alla hüpata!" karjub mees telefoni. - "Ja mis siis? Kas aken on kinni kiilunud ja te ei suuda seda avada?" küsib politseinik lahkelt.]

(Humor o teściowej 8/93: 27)

Suur osa poola ämmanaljadest on leitavad ka internetist. Peamiselt on tegu musta huumori näidetega, kusjuures need naljad ei ole viimase kümnendi vältel eriti muutunud.

Idzie Masztalski z obita, sina buźka i taszczy duże walizki. Spotyka przyjaciela: "Co Ci się stato Masztalski?”

"A, teściowa mnie pobita."

"Jak by mnie tak teściowa pobiła, to bym ja chyba poćwiartowat!”

"A ty myślisz, że co ja tu dźwigam w tych walizach?"

[Härra Masztalski näib olevat peksa saanud, ta on näost sinine ja kannab raskeid kohvreid. Ta kohtab oma sõpra: "Mis juhtus?" - "Mu ämm peksis mu läbi." - "Kui minu oma oleks seda teinud, oleksin ta tükkideks lõiganud!” - “Ja mis mul siis sinu arust siin kohvrites on?”]

(www.pol.pl/humor)

Naljades on ämm esitatud perekonna peamise vaenlasena ja inimesena, kes ohustab tõsiselt pereõnne; ta on intensiivse agressiooni objekt. Selleteemalised naljad olid traditsiooniliselt populaarsed aegadel, mil elamispinnaga oli 
probleeme ja noorpaarid olid sunnitud oma vanematega koos elama. Viimastel aastakümnetel on sotsiaalmajanduslik olukord selles osas muutunud ja üha rohkem paare saab endale lubada omaette elamist, seega on sellised naljad küll kollektiivses mälus ja veebis olemas, kuid enam mitte nii produktiivsed. ${ }^{5}$

\section{Majapidamistööd}

Poola kultuuris on naise roll olnud traditsiooniliselt ja rangelt seotud kodus olemisega, koduperenaisena teeb ta kõiki erinevaid kodutöid. Üks paljudest ülesannetest on toiduvalmistamine, mida juba vanadest aegadest on peetud teiste pereliikmete eest hoolitsemise ja neisse hästi suhtumise märgiks. Selle uskumusega seoses on palju nalju süüa tegevatest naistest.

"Co ci zrobita żona, że ja tak strasznie zwymyślateś?"

"Jak to co ?! Obiad!”

["Mis su naine tegi, kui sa temaga niimoodi kärkisid?" - "Mis ta teha sai? Tegi lõunasöögi."]

(Coś z dowcipami. O facetach 11/12, 1997)

Valmistatud toidu kohta öeldakse tavaliselt, et see ei ole hea:

Co dostanę, jeśli codziennie będę ci gotować takie pyszne obiady jak dziś? Najpóźniej za trzy lata sto milionów złotych z tytułu mojego ubezpieczenia na życie ...

[Pärast sööki küsib noor abielunaine oma mehelt: "Mis ma selle eest saan, et sulle iga päev selliseid maitsvaid õhtusööke teen?" - "Sada miljonit zlotti mu elukindlustusfirmalt, hiljemalt kolme aasta pärast."]

(100 Dowcipów na każdą okazję 2/97)

Toit on pereelu keskmes, ja mitte ainult ühise laua taga söömisel, mida peetakse perega veedetud kvaliteetajaks, mil pereliikmed saavad rääkida ja jagada oma igapäevaseid kogemusi, vaid ka seetõttu, et stereotüüpne poola ema on pidevalt mures, et ta lapsed piisavalt ei söö.

Zdenerwowana mama do córeczki: "Wiesz co się dzieje z małymi dziewczynkami, które nie zjadają wszystkiego z talerza?!”

"Wiem, pozostają szczupłe, zostaja modelkami i zarabiają kupę forsy..." [Vihane ema pahandab oma tütrega: "Kas sa tead, mis juhtub väikeste tüdrukutega, kes oma taldrikut tühjaks ei söö?” - “Jah, ma tean, nad jäävad saledaks, neist saavad modellid ja nad teenivad palju raha..."] (http://wienmar.republika.pl/dowcipy.htm) 
Suur osa ühiskonnast eeldab siiani, et naised peavad vastutama kõigi majapidamistööde eest. Kuigi täiskohaga töötavatel naistel jääb vähem aega kodutööde tegemiseks kui tüüpilistel koduperenaistel, kulutavad nad siiski selleks palju rohkem aega kui nende abikaasad. Tänapäeval on paljude perede elu teistsugune kui traditsioonilises peremudelis, kus mees teenib perele elatist ja naise päev möödub majapidamistöid tehes ning laste eest hoolitsedes. Kuid muutused ühiskonnas ei ole siiani kaasa toonud muutusi stereotüüpides või naljades. Mehi nähakse ikka avaliku elu kontekstis ja professionaalsel ametikohal, samas kui naisi kujutatakse pereelu privaatsfääris. Paljud täiskasvanud poolakad väidavad ikka veel, et naine saab õnnelik olla ainult kodus (Nowakowska \& Piwnik).

Dlaczego sołtys kupit żonie samochód bez silnika?

Bo uważa, że miejsce kobiety jest $w$ domu!

[Miks ostis külavanem oma naisele ilma mootorita auto?

Sest ta arvab, et naise koht on kodus!]

(www.pol.pl/humor)

\section{Avalik sfäär}

Naljades ei kujutata naisi peaaegu kunagi oma töökohal; kui seda siiski tehakse, töötavad nad kas haiglas, kontoris või koolis, ja teevad kõige vähem tasustatavaid töid, nagu koristamine, põetamine või õpetamine.

Kõige rohkem on nalju õpetajatest; naisõpetajal on neis tavaliselt toetav roll, samas kui koolis toimuvate sündmuste peategelane on õpilane:

Nauczycielka narysowała na tablicy trójkąt bez jednego boku.

"Jasiu,” pyta, "czego brakuje w tym trójkacie?”

"Kredy!"

[Õpetaja on joonistanud tahvlile kolmnurga, millel puudub üks külg. "Jasiu, mis sellel kolmnurgal puudu on?" küsib ta. - "Kriit!"]

(Coś z dowcipami. O facetach 11/97)

Töötav naine võib naljades olla majahoidja, lapsehoidja, haigla põetaja, assistent, kassapidaja, poemüüja ja koristaja. Samas on töötavate naiste kohta käivaid nalju suhteliselt vähe, arvestades naiste tööhõivet ühiskonnas (vt ka Laineste 2012). Naljades on tööl käivad naised tavaliselt laisad, rumalad, naiivsed ja kohmakad.

Dyrektor przyjmuje kandydatkę do pracy. Oświadcza, że stanowisko może być powierzone tylko osobie odpowiedzialnej.

“Co do tego może pan być zupetnie spokojny,” odpowiada dziewczyna. 
“Tam, gdzie pracowatam do tej pory, za każdym razem, gdy coś nie wychodzito, mówiono, że ja jestem odpowiedzialna."

[Meesülemus võtab tööle naise ja ütleb talle, et sellel ametikohal saab töötada ainult vastutustundlik inimene. "Te võite selles täiesti kindel olla," vastab neiu. "Kõikides kohtades, kus ma siiamaani olen töötanud, oli nii, et kui midagi läks valesti, öeldi, et mina vastutan selle eest."]

(100 Dnko 7/97)

Sekretäridena töötavaid naisi kujutatakse sageli bosside armukestena.

Rozmawia dwóch dyrektorów: "Podobno masz nowa sekretarkę?"

"Owszem."

"I jesteś z niej zadowolony?"

"Po pierwszym dniu trudno powiedzieć..."

"Młoda, tadna?"

"Taka sobie..."

"A jak się ubiera?"

"Bardzo szybko."

[Kaks juhti räägivad omavahel. "Räägitakse, et sul on uus sekretär?" - "Jah, nii see on." - "Ja kas sa oled temaga rahul?" - "Seda on pärast esimest päeva raske öelda..." - "On ta noor ja ilus?" - "Üsnagi..." - "Ja kuidas ta riietub?" - "Väga ruttu."]

(http://sekretarki.dowcipy.pl/)

\section{Tegevused vabal ajal}

Umbes 5\% naljadest käsitleb naisi vaba aja tegevustes, mis stereotüüpselt ei ole muud kui tagarääkimine, poodides käimine ja teleri vaatamine. Sellistes naljades ei võta naised osa spordiüritustest või pidudest, ning sageli peavad mehed naisi neist sündmusest vähemolulisemaks:

"Ważniejszy ci ode mnie mecz piłki nożnej!” złości się żona.

"Wybacz, kochanie,” wzdycha mąż, “ale i rozgrywki w koszykówce. No $i$ boks," dorzuca po chwili.

[“Jalgpallimäng on sulle tähtsam kui mina!" kaebab naine. - "Vabandust, kallis," ohkab mees, "aga sama on ka korvpalliga. Nojah, ja poksiga samuti," lisab ta hiljem.]

(http://humor.pl/kobieta_i_mezczyzna/708) 
Samas on tavaliselt just meestel võimalus kodus teleri ees lõõgastuda, ja nad eelistavadki seda teha, selle asemel et näidata üles huvi oma naise ja laste suhtes. Järgnev nali näitab televisiooni destruktiivset mõju pereelule:

Rozmawiaja dwa przedszkolaki.

"Mój tatuś bawi się ze mną!"

"Mój te $\dot{z}$, ale tylko wtedy gdy jest zepsuty telewizor."

[Kaks lasteaialast räägivad omavahel.

"Minu isa mängib koos minuga!" - "Minu isa mängib ka minuga, aga ainult siis, kui telekas on katki."]

(Dobry Humor. O telewizji 12/1998)

Poes käimine on tavapärane vaba aja veetmise viis. Poola ühiskond on muutumas üha tarbijakesksemaks. Enam ei ole ostlemine pelgalt funktsionaalne või materiaalne, vaid sümbolväärtusega tegevus, mis määratleb inimese identiteedi ja tema koha maailmas, sellest on saanud tähtis hobi. ${ }^{6}$ Naljades käivad naised asju ostmas oma abikaasade kulul või vähemalt nende nõusolekul.

Szatnia w taźni. Na wieszakach wisza ubrania. W pewnym momencie $w$ jednym z nich dzwoni telefon komórkowy. Rozbierajacy się obok mężczyzna wyciaga komórkę: "Cześć kochanie, o co chodzi?" - [...] - "A ile to futro kosztuje? 5000? Trochę drogo, ale dobrze, kup sobie.”

Po zakończeniu rozmowy facet bierze komórkę $i$ wchodzi do pomieszczenia łaźni. Już od drzwi wota: "Chtopaki, czyj to telefon?"

[Ujula riietusruum. Kõikjal on palju riidepuid rippuvate riietega. Järsku heliseb mingi rõivaeseme taskus mobiiltelefon. Üks mees, kes parajasti lahti riietub, võtab telefoni vastu: “Tere, kallis, mis on?” - [...] - “Ja kui palju see karusnahk maksab? 5000? Natuke kallivõitu, aga osta pealegi.”

Kui telefonikõne on lõppenud, võtab mees telefoni ja siseneb saunaruumi. Ta hõikab: "Mehed, kelle oma see telefon on?"

(http://www.dowcipy.org/d_roz.php)

\section{Kokkuvõte}

Enamikus naljadest kujutatakse naist ikka veel pereseostes: kas abikaasa, armukese, ema või ämmana. Kõige tavalisem skript on naiste kui abikaasade ja armukeste truudusetus. Üldiselt võib öelda, et seda tüüpi naljades domineerib vastandus seks / seksi puudumine. Ema-teemalised naljad tõstavad esile naise hoolivust, ämma-teemalised viha ja hirmu. Naised teevad ära enamiku majapidamistöödest (eriti toiduvalmistamise ja koristamise) ja suuresti on nende 
õlgadel ka vastutus laste eest. Peamiselt ongi see ema, kes oma last, tavaliselt poega, aitab. Täiskasvanud tütred esinevad naljades sagedamini koos ema kui isaga - emaga vahetatakse negatiivseid kogemusi meeste kohta.

Ema-teemalisi nalju kohtab Poolas palju vähem kui neid, kus peategelaseks on ämm, kelle üldiseks tunnusjooneks on agressiivsus. Naljades esinevad naised ei pea mitte ainult armukesi, vaid on ka abielu purunemise põhjustajad, seega leidub märkimisväärselt palju nalju lahutustest. Kuid kõige sagedamini kujutatakse naist oma joodikust mehe vihase abikaasana. Poola mehed saavad kokku baarides, ja kui nad sealt koju lähevad, püüavad nad otsida vabandusi ja tõestada raevukatele abikaasadele oma süütust.

Peaaegu mitte kunagi ei kujutata naljades naisi töökohal. Ühiskonnas toimunud muutused ei ole suutnud veel stereotüüpe muuta, mehi kujutatakse ikka avaliku elu kontekstis ja ametialases positsioonis, samas naisi näidatakse pereelu privaatsfääris.

Poola naljade analüüs näitab, et mõned naljatüübid on nii-öelda kivinenud (nt ämma-teemalised), kuid on tekkinud ka uusi nalju uudsete teemadega, nt vaenulikkus kellegi teise ämma suhtes. Üllataval kombel ei ole nalju isapuhkusest, mis sai võimalikuks alles hiljuti ja oli ka meedias laialt kajastatud. Samuti ei esine nalju naiste joomise kohta, kuigi probleem on ühiskonnas olemas ja naistel on üha rohkem lubatud avalikes kohtades alkoholi tarbida. Perenaljades ei käsitleta kõiki päevakajalisi teemasid, pigem on need naljad jäänud peamiselt traditsiooniliseks, on teatud korduvad naljatüübid, mis saavad ainest kultuuripärandist ja pole eriti produktiivsed, kuid nad on siiski olemas.

Tõlkinud Mall Leman

\section{Kommentaarid}

1 Nali on "lühike narratiiv-dialoogiline tekst, mis lõpeb puändiga ja mille eesmärgiks on põhjustada naeru" (Raskin 1985: 81). Semantilisel tasandil koosneb nali vähemalt kahest vastandskriptist. Skript on "suur kogum sõnaga kaasas käivat või assotsieeruvat semantilist teavet. Teksti saab kirjeldada kui ühte nalja kandvat teksti, kui on täidetud kaks tingimust: 1) tekst ise peab sobituma, kas osaliselt või täielikult kahe erineva skriptiga; 2 ) nende kahe skripti vahel peab tekkima vastandus" (samas).

2 Statistika järgi joovad poolakad vähem alkoholi (10,6 l) kui teiste Euroopa Liidu riikide rahvad keskmiselt (10,85 liitrit iga 15aastase ja vanema inimese kohta). 2011. aastal tarbis iga inimene Poolas keskmiselt 3,7 l kangeid alkohoolseid jooke, 6,1 l õlut ja 0,4 l veini (vt egospodarka.pl: http://www.egospodarka.pl/79723,Spozycie-alkoholuw-Polsce-nizsze-od-sredniej-UE,1,39,1.html).

3 Viljakuse määr oli 1,38 (2010) ja loomulik iive 0,3\% (2011) (vt GUS 2012: http://www. stat.gov.pl/cps/rde/xbcr/gus/f_polska_w_liczbach_2012.pdf). 
4 Poola üks kõige kiiremini arenevaid ja suurimaid lingvistikakoolkondi tegutseb Lublinis, selle asutajaks on professor Jerzy Bartmiński, ja see tegeleb keelelise maailmapildi uurimisega. Lublini etnolingvistika koolkond kuulub antropoloogilise ja kognitiivse lingvistika valdkonda; lähtepunktiks oli dialektoloogia ja folkloori uurimine, kuigi päris algusest peale on saadud inspiratsiooni kultuur-antropoloogilisest lingvistikast. Uuringud hõlmavad poola rahvakeelt, rahvaluuletekstide keelt ja poeetikat, poola keelt üldiselt, kõnekeelt ja selle sisemist mitmekesisust. Arvesse võetakse ka komparatiivseid, intralingvistilisi ja intrakultuurilisi aspekte. Üks selle koolkonna uurimismeetodeid on profileerimine - see erineb pisut Langackeri metoodikast. Selle eestvedajaks on Jerzy Bartmiński ja tema kolleegid. Profileerimine tähendab "mingi objekti esitamist erinevatest perspektiividest, mõiste formeerumist vastavalt sellele, kuidas mingi konkreetne subjekt sellele viitab". Profiilid on "subjektiivselt relativiseeritud tähenduse variandid, mis tekivad sama objekti subjektiivsest kontseptualiseerimisest" (Bartmiński 1993: 272).

5 Peaaegu pooled noortest (48,3\%) väidavad, et nad on rahul oma elamistingimustega, kuigi sooviksid, et kodulaenu või mingit muud finantstoetust oleks hõlpsam saada, et ehitada endale maja või osta uus korter (Młodzi 2011).

6 Üks uusimaid sotsiaalseid probleeme on nii meeste kui naiste puhul kompulsiivne ostusõltuvus (vt Natręctwo kupowania: http://www.uzaleznienia.info/index.php?option=com content\&view=article\&id=68:natrectwo-kupowania\&catid=15\&Itemid=122). Tänapäeva naiste tarbimisharjumuste analüüsi vt Nowalska 2007.

\section{Allikad}

\section{Perioodilised huumoriväljaanded (1995-1998)}

Dowcip za dychę [Naljad kümneka eest]. Warszawa: Naja-press.

Humor [Huumor]; Humor Szkolny [Koolinaljad]; Śmiechu Warte. Wybór najlepszychdowcipów z prasy humorystyczno-satyrycznej [Naeruväärne. Parimad naljad ajakirjandusest]. Warszawa: K.M.S.O. Sp. z o.o..

Najlepsze Dowcipy. Ogólnopolski miesięcznik humoru [Parimad naljad. Poola huumoriajakiri]. Koszalin.

Super Dowcipy [Supernaljad]; Dowcip Miesiąca [Kuu anekdoot]; Dobry Humor [Head naljad]; O kurach 8/1996 [Kanadest]; O telewizji 12/1998 [Televisioonist]; 103 Najlepsze Dowcipy [103 parimat anekdooti]. Superpress.

Świeże Dowcipy Prosto z Komputera [Värsked naljad otse arvutist]; Coś z dowcipami [Naljadest]; O facetach 11/97 [Meestest]; Ale Jaja. O kobietach 12/97 [Aga munad! Nalju naistest]. Warszawa: Podulkastudio.

100 Dnko - 100 Dowcipów na każdą okazję [100 anekdooti igaks elujuhtumiks]. Warszawa.

Humor matżeński [Anekdoote abielust]. Humor Kieszonkowy 6/96. Warszawa: Infopress.

Humor o teściowej [Anekdoote ämmadest]. Zamek 8/93. 


\section{Huumorikogumikud}

Hącia, Agata (toim). Humor polski [Poola huumor]. Warszawa: Świat Książki, 2003.

Pektyn, Andrzej \& Pettyn, Remigiusz (toim). Wielka księga anegdot [Suur anekdoodiraamat]. Warszawa: Europa, 1998.

Sieradzcy, Andrzej \& Sieradzcy, Grażyna (toim). Wielka księga humoru polskiego [Suur poola huumorikogumik]. Warszawa: Ethos, 2000.

Mondel, Dorota \& Skierkowski, Marek (toim). Xsięga humoru [Huumorikogumik]. Wrocław: FOX, 1999.

\section{Veebilehed (1995-2012)}

http://alejaja.pl/ - 1. november 2012.

http://dowcipy-o-kobietach.humoris.pl - 1. november 2012.

http://sekretarki.dowcipy.pl - 1. november 2012.

http://wienmar.republika.pl/dowcipy.htm - 1. november 2012.

http://www.dowcipy.celebs.pl - 1. november 2012.

http://www.dowcipy.jeja.pl - 1. november 2012.

http://www.dowcipy.net.pl - 1. november 2012.

http://www.dowcipy.org - 1. november 2012.

http://www.duzohumoru.pl/kawaly - 1. november 2012.

http://www.humorki.pl/p_zagadki.php - 1. november 2012.

http://www.joemonster.org - 1. november 2012.

http://www.kawaly-o-jasiu.dimz.pl/rodzice2 - 1. november 2012.

http://www.kiermana.pl/88-1-twoja,stara.html\#axzz1xZ6VF7sy - 1. november 2012.

http://www.rechot.com/index.php - 1. november 2012.

http://www.sadurski.com/gify - 1. november 2012.

http://www.webhumor.pl/kawaly-dowcipy/kobieta - 1. november 2012.

http://humor.pl/kobieta_i_mezczyzna/708 - 1. november 2012.

\section{Kirjandus}

Bartmiński, Jerzy 1993. O profilowaniu i profilach raz jeszcze [Profiilide koostamisest ja profiilidest]. Bartmiński, Jerzy \& Tokarski, Ryszard (toim). O definicjach $i$ definiowaniu [Mõistetest ja määratlemisest]. Lublin: Wydawnictwo UMCS, lk 269-275. 
Bartmiński, Jerzy 1998. Podstawy lingwistycznych badań nad stereotypem - na przykładzie stereotypu matki [Stereotüüpide lingvistiliste uuringute alused ema stereotüübi näitel]. Anusiewicz, Janusz \& Bartmiński, Jerzy (toim). Stereotyp jako przedmiot lingwistyki. Teoria, metodologia, analizy empiryczne 12 [Stereotüüp lingvistilise uurimise subjektina. Teooria, metodoloogia, empiiriline analüüs]. Wrocław: Towarzystwo Przyjaciół Polonistyki Wrocławskiej, lk 63-83.

Brzozowska, Dorota 2003. Jokes about women in Poland. Čarkić, Miloslav Ž. (toim). Stil 2 [Stiil]. Belgrad: The International Association Style, lk 283-293 (http://www.rastko. rs/filologija/stil/2003/20Brzozowska.pdf - 31. oktoober 2012).

Brzozowska, Dorota 2008. Polish jokes about Jewish women. Kwiatkowska, Alina \& Dżereń-Głowacka, Sylwia (toim). Shades of Humor. Humor: Theories, Applications, Practices 1/2. Piotrków Trybunalski: Naukowe Wydawnictwo Piotrkowskie, lk 149-157.

Brzozowska, Dorota 2009. Polish jokelore in the period of transition. Krikmann, Arvo \& Laineste, Liisi (toim). Permitted Laughter: Socialist, Post-socialist and Never-socialist Humour. Tartu: ELM Scholarly Press, lk 127-169.

Davies, Christie 1990. An explanation of Jewish jokes about Jewish women. Humor: International Journal for Humor Research 3-4, lk 363-378 (doi:10.1515/humr.1990.3.4.363).

Davies, Christie 2002. The mirth of nations. New Brunswick \& London: Transaction Publishers.

Davies, Christie 2011. Jokes and targets. Bloomington: Indiana Univesity Press.

eGospodarka.pl = Spożycie alkoholu w Polsce niższe od średniej UE [Alkoholi tarbimine Poolas madalam kui ELis keskmiselt]. eGospodarka.pl (http://www.egospodarka. pl/79723,Spozycie-alkoholu-w-Polsce-nizsze-od-sredniej-UE,1,39,1.html - 30. oktoober 2012).

Eichelberger, Wojciech 1998. Zdradzony przez ojca [Isa poolt reedetud]. Warszawa: Wydawnictwo DO.

familie.pl = Portal o planowaniu dzieci od poczęcia do wychowania dziecka [Pereplaneerimise ja laste kasvatamise portaal] (http://www.familie.pl/artykul/Bezplodnosc-inieplodnosc-choroby-cywilizacyjne-XXIwieku,1069,1.htm - 04. juuni 2012).

GUS 2012 = Polska v liczbach. Poland in figures. Warsaw: Głowny Ursąd Statystyczny / Central Statistics Office (http://www.stat.gov.pl/cps/rde/xbcr/gus/f_polska_w_liczbach_2012.pdf - 30. oktoober 2012)

Jędrzejko, Ewa 1994. Kobieta w przysłowiach, aforyzmach i anegdotach polskich. Konotacje i stereotypy [Naised poola vanasõnades, aforismides ja anekdootides. Varjundid ja stereotüübid]. Anusiewicz, Janusz \& Handke, Kwiryna (toim). Język a kultura. Pteć $w$ języku $i$ kulturze 9. [Keel ja kultuur. Sugu keeles ja kultuuris]. Wrocław: Wiedza i Kultura, lk 159-172.

Labus, Tomasz 2011. Kultura picia alkoholu. Jak nas postrzegają inne narody? [Joomakultuur. Kuidas me paistame teistele rahvastele?] Wiadomości24.pl (http://www.wiadomosci24.pl/artykul/kultura_picia_alkoholu_jak_nas_postrzegaja_\%20inne_narody_1805822--1-d.html - 30. oktoober 2012). 
Laineste, Liisi 2012. Women in Estonian jokes. Laineste, Liisi \& Brzozowska, Dorota \& Chłopiki, Władysław (toim). Estonia and Poland: Creativity and tradition in cultural communication 1: Jokes and their relations. Tartu: ELM Scholarly Press, lk 33-52.

Młodzi 2011 = Obszary wspólnotowości i intymności: małżeństwo, rodzina, wybory alternatywne. Raport Młodzi 2011 [Valitsuse ülevaade noorte seisukohtadest abielu, perekonna ja alternatiivsete valikute kohta] (http://zds.kprm.gov.pl/sites/default/files/ mlodzi_2011_06.pdf - 30. oktoober 2012).

Natręctwo kupowania = Natręctwo kupowania. Uzależnienia behawioralne [Sundostlemine. Sõltuvuskäitumine] (http://www.uzaleznienia.info/index.php?option=com_content \&view=article\&id=68: natrectwo-kupowania\&catid=15\&Itemid=122-31. oktoober 2012).

Nęcki, Zbigniew 2000. Komunikacja międzyludzka [Suhtlus inimeste vahel]. Kraków: Antykwa.

Nowalska, Dorota 2007. Rekonstrukcja wzorów zachowań konsumpcyjnych wśród kobiet na przyktadzie województwa śląskiego [Tarbijakäitumise mudelite rekonstruktsioon Sileesia naiste näitel]. Katowice: Uniwersytet Śląski (http://www.sbc.org.pl/Content/4452/ doktorat2693.pdf - 30. oktoober 2012).

Nowakowska, Urszula \& Piwnik, Emilia. Kobiety w rodzinie [Naised perekonnas] (http:// temida.free.ngo.pl/raprodzina.htm - 30. oktoober 2012).

Panasiuk, Jolanta 1998. O zmienności stereotypów [Stereotüüpide varieeruvusest]. Anusiewicz, Janusz \& Bartmiński, Jerzy (toim). Stereotyp jako przedmiot lingwistyki. Teoria, metodologia, analizy empiryczne 12 [Stereotüüp lingvistilise uurimise subjektina. Teooria, metodoloogia, empiiriline analüüs]. Wrocław: Towarzystwo Przyjaciół Polonistyki Wrocławskiej, lk 84-98.

Pawlowska, Marta 2012. Polski tata spędza z dzieckiem 53 minuty dziennie. Chce więcej, ale szefowie śmieją się z urlopów tacierzyńskich. Gazeta Wyborcza [Poola isa veedab lapsega 53 minutit päevas. Ta tahab rohkem, kuid ülemused naeruvääristavad isapuhkust] (http://natemat.pl/7239,polski-tata-spedza-z-dzieckiem-53-minuty-dzienniechce-wiecej-ale-szefowie-smieja-sie-z-urlopow-tacierzynskich - 30. oktoober 2012).

Raskin, Victor 1985. Semantic mechanisms of humor. Dordrecht: Reidel Publishing Company (doi:10.1007/978-94-009-6472-3).

Szukalski, Piotr 2011. Małżeństwa powtórne w powojennej Polsce [Taasabiellumine sõjajärgses Poolas]. Wiadomości Statystyczne 4, lk 11-22 (http://www.stat.gov.pl/cps/ rde/xbcr/pts/oz_wiadomosci_statystyczne_4_2011.pdf - 30. oktoober 2012).

Żmudzka-Kosała, Małgorzata 2010. Polska rodzina - kondycja rodziny: terminy, definicje, dane statystyczne [Poola pere - peretingimused: terminid, definitsioonid, statistika]. wychowanie-dziecka.bloog.pl (http://wychowanie-dziecka.bloog. pl/id,328154952,title,Polska-rodzina-kondycja-rodziny-terminy-definicje-danestatystyczne,index.html?ticaid=6f711 -31 . oktoober 2012 ).

Õigusabi portaal $=$ Najnowsze statystyki dotyczące rozwodów. Prawnik-online.eu 22. marca 2012 (http://www.prawnik-online.eu/porady-prawne/najnowsze-statystykidotyczace-rozwodow - 30. oktoober 2012). 


\section{Summary}

\section{Family in Polish jokes}

\section{Dorota Brzozowska}

Keywords: Polish family jokes, nuclear family, stereotypes about women, post-socialist jokelore

The main aim of the research was to describe the image of family life presented in post-socialist jokelore. Contemporary material (from the late 1990s till the present day) consisting of jokes published in books, booklets, newspapers and on the Internet was collected and analysed for this study, altogether 600 jokes. As there is no special cycle of jokes connected with family life, texts of different series were taken into account in which the words "woman", "man", "child" or their synonyms were present. The results showed that there exist a number of stable targets, e.g. aggressive mothers-in-law or adulterous wives. New targets are reluctant to arise: there are no jokes about the paternal leave which was recently introduced and widely discussed in the media, and there are also no jokes about women drinking alcohol, although this problem exists in the society that gives more and more permission to women drinking in public places. We can conclude on the basis of this research that family jokes do not deal with current and topical issues; instead, they have remained mostly traditional with certain recurring cycles being at the core of the Polish cultural heritage. 